\title{
Scale Effects of Footings on Geocell Reinforced Sand Using Large-Scale Tests
}

\author{
A. Shadmand ${ }^{\mathrm{a}}$, M. Ghazavi ${ }^{\mathrm{b} *}, \mathrm{~N}$. Ganjian $^{\mathrm{c}}$ \\ ${ }^{a}$ Ph.D. Candidate, Department of civil Engineering, Science and Research Branch, Islamic Azad University, Tehran, Iran. \\ ${ }^{b}$ Professor, Department of Civil Engineering, K.N. Toosi University of Technology, Tehran, Iran. \\ ${ }^{C}$ Assistant Professor, Department of civil Engineering, Science and Research Branch, Islamic Azad University, Tehran, Iran.
}

Received 18 January 2018; Accepted 20 March 2018

\begin{abstract}
The scale effect on bearing capacity of shallow footings supported by unreinforced granular soils has been evaluated extensively. However, the subject has not been addressed for shallow footings on geocell-reinforced granular soils. In this study, load-settlement characteristic of large square footings is investigated by performing large-scale loading tests on unreinforced and geocell-reinforced granular soils. The effects of footing width (B), soil relative density of soil $\left(\mathrm{D}_{\mathrm{r}}\right)$, and reinforcement depth $(\mathrm{u})$ have been investigated. The test results show that the scale effects exist in geocell-reinforced soils, like unreinforced soils, and the behavior of small-scale models of footings cannot be directly related to the behavior of full-scale footings due to the difference between initial conditions of tests and the initial state of mean stresses in the soil beneath the footings having different dimensions. Large footings create higher mean stresses in the soil, resulting in low soil friction angle and initial conditions of the test approach to the critical state lines. The results of tests indicate that model experiments should be conducted on low-density soil for better prediction of the behavior of full-scale footings, otherwise, the predicted behavior of full-scale footings does not seem conservative.
\end{abstract}

Keywords: Scale Effect; Geocell; Shallow Footing; Large-Scale; Sand.

\section{Introduction}

Geocell consisting of three-dimensional honeycomb-shaped structure has been of significant interest in recent years for geotechnical engineers due to its reasonable price, ease of use, good tensile strength, higher bending stiffness compared with planar geosynthetics, high durability and environmental considerations. The better performance of geocell than planar reinforcements (e.g. geogrid and geotextile) in increasing the bearing capacity and reducing the settlement of shallow footings is well known [6-10]. A numerical simulation of geocell-reinforced foundation beds using FLAC 3D was reported by Oliaei and Kouzegaran. In this study, a comparison was made between the performance of cellular geosynthetic reinforcement and a planar form with the same mass of used material [23]. Hegde and Sitharam have performed many numerical and experimental studies to investigate the behavior of the footings supported on geocell, geocell with additional basal geogrid reinforced soil and bed reinforced with the bamboo cells. They reported that planar geogrid at the base of the geocell layer increased the load carrying capacity significantly [16, 17 and 18]. Shadmand et al. [24] used geocell with an opening reinforcement as the bed for large scale footings for the first time. They showed that using geocell with opening like full geocell can improve load-settlement characteristics of footings. In 1963, De Beer showed that the bearing capacity coefficient $\left(\mathrm{N}_{\gamma}\right)$ was not only a function of the soil internal friction angle of the soil ( $\Phi$ ) but also the value of $\mathrm{N}_{\gamma}$ decreased with increasing the footing dimensions (B) in the granular soil.

\footnotetext{
* Corresponding author: ghazavi_ma@kntu.ac.ir

doil http://dx.doi.org/10.28991/cej-0309110

$>$ This is an open access article under the CC-BY license (https://creativecommons.org/licenses/by/4.0/).

(C) Authors retain all copyrights.
} 
This is called the scale effect [11] and confirmed by performing tests [19, 25, 28]. In addition, the ratio of footing width to mean diameter of soil grains is also affected the $\mathrm{N}_{\gamma}$ value in small-scale footings [20]. According to test results obtained by Golder and De Beer, the mean stress of the soil beneath the footing varies according to footing dimensions. As the footing dimensions increase, the mean stress rises and the amount of $\Phi$ declines consequently according to the Mohr-Coulomb failure envelop, leading to a decrease in $\mathrm{N}_{\gamma}$ and bearing capacity of the footing. In other words, considering the concept of critical state in the soil, it can be said that a large footing imposes a greater mean stress on the soil, which approaches to the critical state line even at the same relative density. Thus, its behavior seems to be similar to that located on a loose soil, compared with smaller footings. Accordingly, small footings show higher amounts of $\mathrm{N}_{\gamma}$ and bearing capacity than large footings. Therefore, the behavior of small-scale footings in laboratory studies cannot be directly used for behavior estimation of full-scale footings and thus the scale effect should be taken into account $[11,15]$.

The scale effect seems more complicated in reinforced granular soils due to numerous parameters such as pocket size, stiffness, width, depth and height of the reinforcement. To the best knowledge of the authors, the scale effect has not been studied yet in geocell reinforced soils and in this research, for the first time, the scale effect and the effect of width of footing supported on geocell has been investigated by using different size of the loading plates. Although the behavior improvement of footings on geocell reinforced soils is obvious, the results of small-scale experiments cannot be directly applied for the design and construction of full scale footings. Moreover, laboratory studies on geocellreinforced soils are often limited to small footings. Adams and Collin conducted the only experimental study in which the dimensions of footing placed on geocell-reinforced soil were changed and a large footing was used. In their study, 7 square load plates of different dimensions were tested next to each other in a test tank. In their study, the effects of boundaries and adjacent footings on each other were not considered due to the proximity of boundaries and footings [1]. Some studies showed that the adjacent footings placed on reinforced soil have a different load-settlement characteristic compared with single footings [14, 21, 22]. For the first time, in this study, using large loading plates, a more accurate estimation of the behavior of the full-scale footings supported on geocell-reinforced sand can be presented.

In this study, 18 large-scale plate load tests are performed using square plates with different dimensions placed on unreinforced and geocell reinforced soils. This study aims to better understand the behavior of footings placed on geocell-reinforced sand and to more study the parameters affecting the scale effect for economic and safe design of this type of footings. The parameters investigated in this research include the footing width (B), relative density of sand bed $\left(D_{\mathrm{r}}\right)$ and reinforcement depth $(\mathrm{u})$.

\section{Laboratory Studies}

\subsection{Sand Bed}

A poorly graded sand is used in this study, which is classified as SP in the Unified Soil Classification System (USCS). Figure 1 illustrates the soil particle size distribution and Table (1) represents physical properties of the soil. The tests are carried out in two relative densities of $35 \%$ and $65 \%$. The internal friction angle corresponding relative densities of $35 \%$ and $65 \%$, which obtained through the drained triaxial compression test, are $38^{\circ}$ and $41^{\circ}$, respectively.

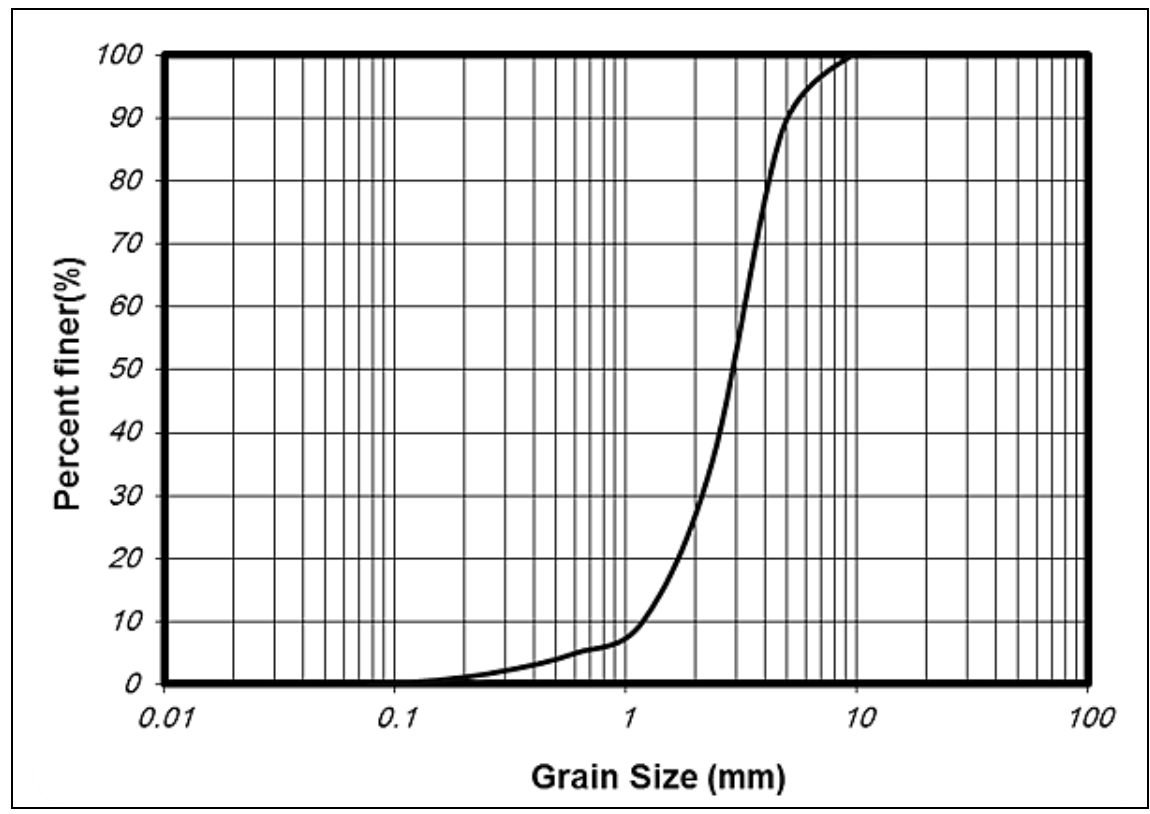

Figure 1. Particle size distribution curve of sands used in this study 
Table 1. Properties of the sand used in the study

\begin{tabular}{cc}
\hline Description & Value \\
\hline Effective particle size, $\mathrm{D}_{10}(\mathrm{~mm})$ & 1.2 \\
$\mathrm{D}_{30}(\mathrm{~mm})$ & 2.1 \\
Mean particle size, $\mathrm{D}_{50}(\mathrm{~mm})$ & 2.9 \\
$\mathrm{D}_{60}(\mathrm{~mm})$ & 3.2 \\
Curvature coefficient, $\mathrm{C}_{\mathrm{c}}$ & 1.15 \\
Uniformity coefficient, $\mathrm{C}_{\mathrm{u}}$ & 2.7 \\
Minimum dry unit weight, $\gamma_{\mathrm{dmin}}\left(\mathrm{kN} / \mathrm{m}^{3}\right)$ & 15.1 \\
Maximum dry unit weight, $\gamma_{\mathrm{dmax}}\left(\mathrm{kN} / \mathrm{m}^{3}\right)$ & 18.6 \\
\hline
\end{tabular}

\subsection{Geocell Layer}

In the current research, considering large footing dimensions, prefabricated factory manufactured geocell was used. To satisfy scale laws to generalize model test results to full scale ones, the stiffness of reinforcement should be smaller than that of real conditions [13]. Therefore, geocells made of perforated geomembrane plates with ultimate tensile strength of $15 \mathrm{kN} / \mathrm{m}$ were used in this study. Hegde and Sitharam used the geocell made of geogrid with ultimate tensile strength of $20 \mathrm{kN} / \mathrm{m}$ in their study $[16,17]$. The pocket size of geocell (d) is taken as the diameter of an equivalent circular area of the pocket opening (Ag). Given the high cost and time-consuming process of large-scale tests, geocell parameters including the pocket size $(\mathrm{d})$, geocell layer height $(\mathrm{H})$ and geocell layer width (b) are considered 220, 150 and $2500 \mathrm{~mm}$, respectively. Geometric and engineering properties of the geocell used in this study are listed in Table 2.

Table 2. Properties of geocell used in current tests (Geoplas data sheet)

\begin{tabular}{cc}
\hline Property & Value \\
\hline Material & Polymeric nano-composite alloy \\
Cell wall surface & Perforated \\
Seam weld strength $(\mathrm{kN} / \mathrm{m})$ & 29 \\
Cell height $(\mathrm{mm})$ & 150 \\
Distance between weld seams $(\mathrm{mm})$ & 400 \\
Cell dimension $(\mathrm{mm})$ & $300 \times 250$ \\
Yield tensile strength $(\mathrm{kN} / \mathrm{m})$ & 15 \\
\hline
\end{tabular}

\subsection{Large-Scale Loading Tests}

The load frame is designed with a negligible deformation under the force of up to $250 \mathrm{kN}$, in accordance with the reaction force applied to the load plate. Diagonal members are used in two directions perpendicular to each other to reduce the deformation of beam, columns and foundation of load frame. Figure 2 illustrates the large-scale load frame used in this study.

Large-scale tests are carried out in reinforced concrete tank with inside dimensions of $3000 \mathrm{~mm}$ length, $3000 \mathrm{~mm}$ width and $2000 \mathrm{~mm}$ height. The size of tank is in accordance with a report about large-scale square shallow footings by Ueno et al. [28]. The walls of tank were lubricated to reduce the friction effect of the tank walls on the test results. Four square steel plates measuring 150, 250, 500 and $600 \mathrm{~mm}$ wide and $30 \mathrm{~mm}$ thick are used as rigid footing models. To prepare a rough surface for the footing bottom, coarse sand paper was adhered to the plates.

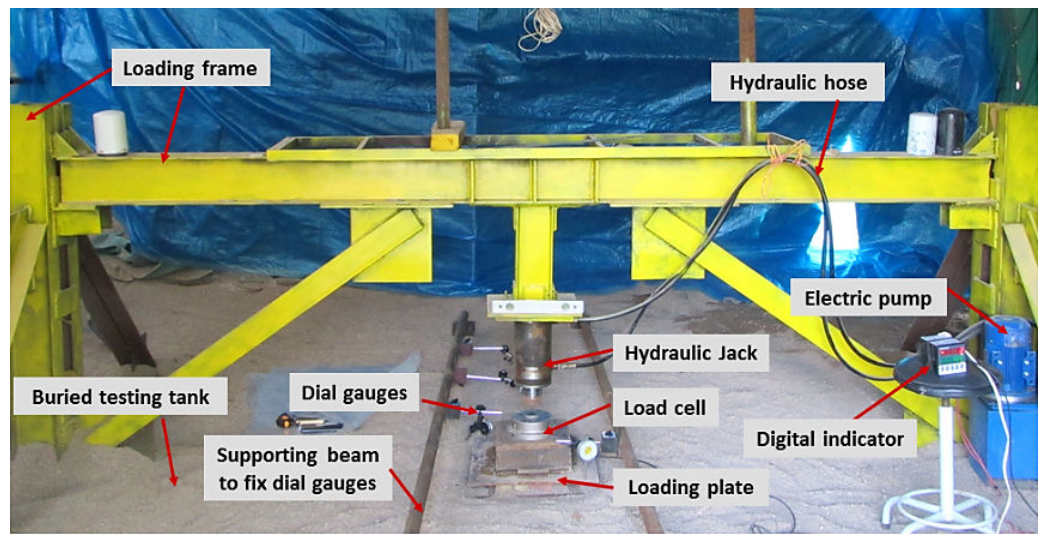

Figure 2. General arrangement of test setup [24] 
The Load applied to the footings was provided by a hydraulic jack with a maximum stroke of $150 \mathrm{~mm}$ and a maximum load capacity of $220 \mathrm{kN}$. The lubrication and semi-spherical shape of contact surface between the load cell and jack shaft prevents excessive moments during loading. The footing settlement was measured using three dial gauges with accuracy of $\pm 0.01 \%$ of ultimate capacity $(100 \mathrm{~mm})$ placed at the corners of the loading plates (Figure 3). A compression load cell with accuracy of $\pm 0.02 \%$ of ultimate capacity, located between the tip of the jack shaft and the loading plate, was used to measure the force applied to the loading plate.

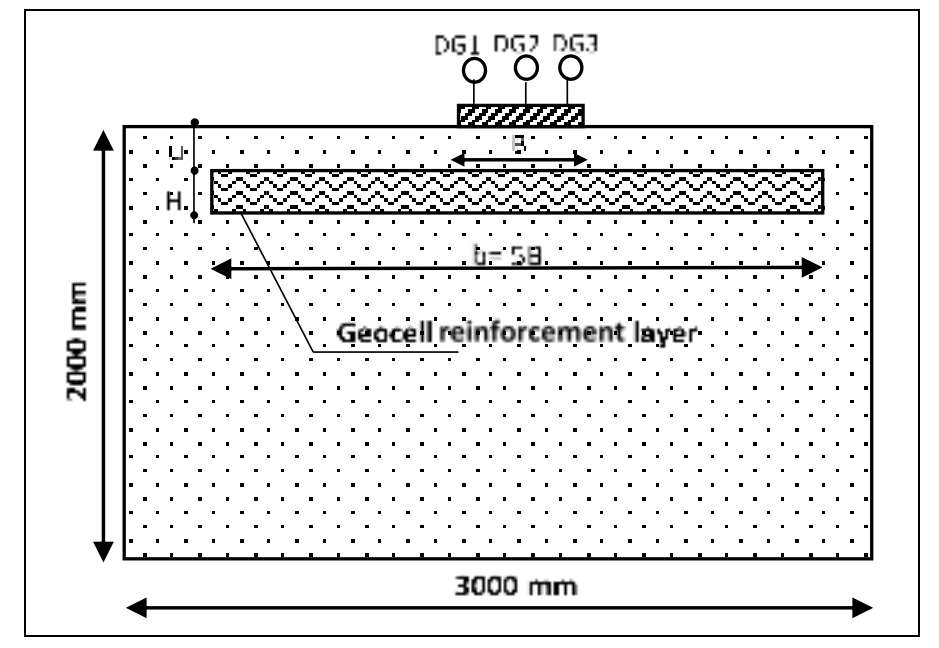

Figure 3. Schematic view of geocell reinforcement and contributing parameters

\subsection{Preparation Method of Specimens and Tests Steps}

To prepare specimens and the test bed in all tests, the sand was poured inside the test tank and compacted in thickness of $200 \mathrm{~mm}$. The tests were conducted on sands with relative densities of $35 \%$ and $65 \%$. Compaction technique was used in the test tank to achieve these densities, according to methodology used by Lavasan and Ghazavi [21]. In sand compaction, a $12 \mathrm{~kg}$ hammer falls 6 and 15 times from a $600 \mathrm{~mm}$ height on a steel square plate measuring $500 \times 500 \times$ $5 \mathrm{~mm}$ to reach relative densities of $35 \%$ and $65 \%$, respectively. To ensure the uniform compaction of different layers and measure the density of compressed soil, three small aluminum containers were placed at different points of the test tank within all layers, in which the density of soil was calculated after the compaction (Figure 4). In all tests, a specific location was selected for containers to ensure identical effects of sampling containers on the results. The maximum difference between measured densities was about $1.5 \%$.

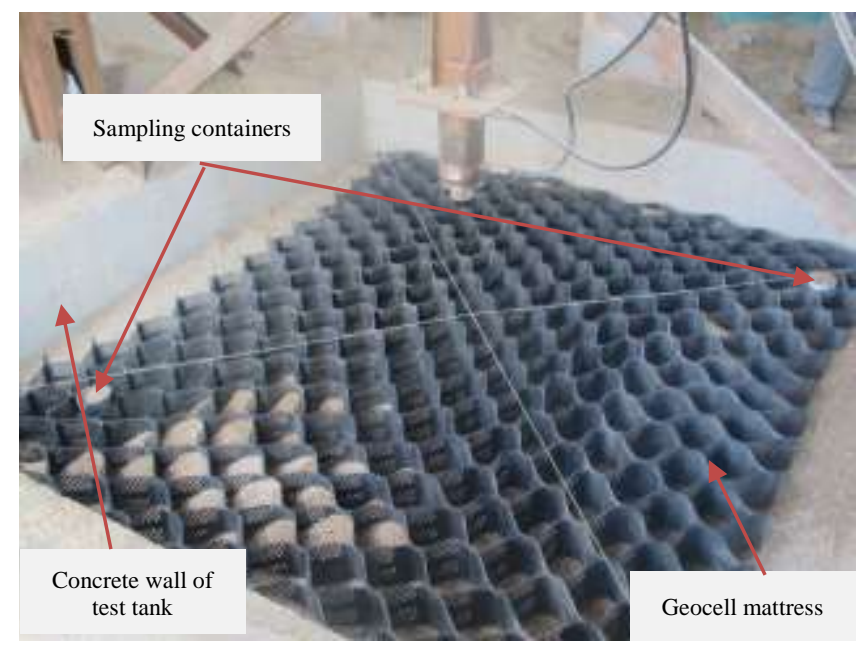

Figure 4. Test tank and geocell mattress

The upper surface of layers was leveled using a long metal ruler and the thickness of each layer was checked according to the marks on inner walls of the tank. When the depth determined for placement of reinforcement was reached, the geocell layer was spread over the surface and the sand was poured and compacted into its pockets and upper surface to the base of footing. When the sand bed was prepared, the load plate was located in the center of test tank and the load cell was placed in the center of load plate. Finally, three dial gauges were installed to measure settlement, in accordance with Figure 3. The Loading was performed according to the ASTM-D1196M [3]. Loading steps were increased when the rate of settlement was less than $0.03 \mathrm{~mm} / \mathrm{min}$ for three minutes. Loading continues until failure in the soil bed or reaching the maximum capacity of the jack. Given the large dimensions of test tank, preparation of each 
specimen took averagely 76 person-hour work.

\subsection{Test Parameters and Programs}

Figures 3 and 5 represent geometric parameters of the tests. Five series of tests were conducted on footings placed on unreinforced and geocell reinforced sand, according to Table 3.

Test series 1 were carried out by changing the dimensions of footing on unreinforced sand at a higher density in order to provide a comparative criterion for the reinforced state. The test series 2 were carried out on unreinforced soil at a lower relative density in order to provide a comparative criterion for the reinforced status. Test series 3 and 4 were conducted on geocell reinforced soil to evaluate the effect of footing dimensions on scale effect. In test series 5, the effect of the depth of geocell layer $(\mathrm{u})$ on the behavior of footing placed on reinforced soil was investigated. Some tests were repeated to assess the repeatability of experiments and control the model errors. The maximum differences between the bearing pressures at a same settlement obtained from two trial tests were around $9 \%$ which shows that testing procedure is accurate and reliable.

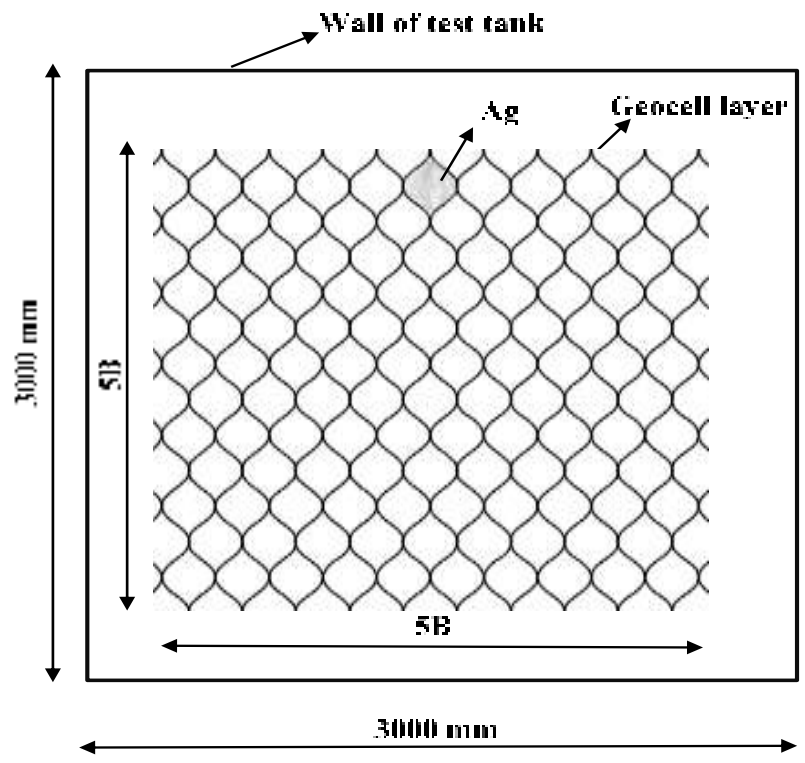

Figure 5. Plan of geocell layer and contributing parameters

Table 3. Details of large scale test program

\begin{tabular}{ccccc}
\hline Test series & Reinforcement type & Variable parameter & Constant parameters & No. of tests \\
\hline 1 & Unreinforced sand & $\mathrm{B}=150,250,500,600 \mathrm{~mm}$ & $\mathrm{D}_{\mathrm{r}}=65 \%$ & $4+1^{*}$ \\
2 & Unreinforced sand & $\mathrm{B}=250,500 \mathrm{~mm}$ & $\mathrm{D}_{\mathrm{r}}=35 \%$ & 2 \\
3 & Geocell & $\mathrm{B}=150,250,500,600 \mathrm{~mm}$ & $\mathrm{u}=50 \mathrm{~mm}, \mathrm{D}_{\mathrm{r}}=65 \%$ & $4+1^{*}$ \\
4 & Geocell & $\mathrm{B}=250,500 \mathrm{~mm}$ & $\mathrm{u}=50 \mathrm{~mm}, \mathrm{D}_{\mathrm{r}}=35 \%$ & 2 \\
5 & Geocell & $\mathrm{u}=50,150,270,450 \mathrm{~mm}$ & $\mathrm{~B}=500 \mathrm{~mm}, \mathrm{D}_{\mathrm{r}}=65 \%$ & $4+1^{*}$ \\
\hline
\end{tabular}

${ }^{*}$ Number of Tests conducted for verification, repeatability and accuracy for test data

\section{Results and Discussion}

\subsection{Introduction of Parameters Studied in the Results}

In 1943, Terzaghi proposed the first general equation for bearing capacity of rigid shallow footings (Equation 1).

$$
q_{u l t}=c N_{c}+q N_{q}+0.5 B \gamma N_{\gamma}
$$

Where $\mathrm{c}=$ cohesion of soil $\left(\mathrm{kN} / \mathrm{m}^{2}\right), \gamma=$ unit weight of soil $\left(\mathrm{kN} / \mathrm{m}^{3}\right), \mathrm{q}=\gamma \mathrm{D}_{\mathrm{f}}\left(\mathrm{kN} / \mathrm{m}^{2}\right), \mathrm{D}_{\mathrm{f}}=$ depth of footing embedment $(\mathrm{m}), \mathrm{B}=$ footing width $(\mathrm{m})$, and $\mathrm{N}_{\mathrm{c}}, \mathrm{N}_{\mathrm{q}}, \mathrm{N}_{\gamma}$ are dimensionless bearing capacity factors and a function of the soil friction angle, according to equations proposed by Terzaghi [27].

Equation (1) may be written in form of Equation (2) in this study for the special case of shallow footing, fully granular soil and square footing. 
$q_{u l t}=0.5 B \gamma N_{\gamma} s_{\gamma}$

where $s_{\gamma}=$ shape factor. The value of $s_{\gamma}$ is dependent on aspect ratio (L/B). Given that, all footings in this research are square the aspect ratio equal 1 and $s_{\gamma}=0.8$ is considered. Decreasing $\mathrm{N}_{\gamma}$ with increasing B was termed the "scale effect" by De Beer. As stated in the introduction, the changes of $\mathrm{N}_{\gamma}$ were used to investigate the scale effect in footings placed on unreinforced soil. In this research, $\mathrm{N}_{\gamma}$ values were back-calculated using Equation (2) to assess the scale effect in reinforced/unreinforced cases.

In load-settlement curves of the geocell reinforced soil, the signs of failure are not clearly visible. Dash et al. and Hegde and Sitharam reported similar results for geocell reinforced soils in small-scale experiments [6,16 and 17]. Therefore, the bearing capacity $\left(\mathrm{q}_{\mathrm{ult}}\right)$ was considered equivalent to the bearing pressure in settlement ratio of $\mathrm{s} / \mathrm{B}=10 \%$, in this study. It is a good assumption due to variability of footing dimensions that considers identical deformation ratios. Cerato and Lutenegger made the same assumption for determination of $\mathrm{qutt}_{\text {[15] }}$.

Normally the effect of soil reinforcement on the footing load-carrying characteristics is determined using the bearing capacity ratio (BCR) [12, 14 and 27]. According small-scale experiments on footings placed on geosynthetics reinforced soils, the ultimate bearing capacity of these systems occurs at very high settlements which do not usually happen in practice [9]. Therefore, the dimensionless parameter of improvement factor (IF) was used in this paper to evaluate the effect of reinforcement.

$I F=\frac{q_{\text {rein }}}{q_{\text {unrein }}}$

where $\mathrm{q}_{\mathrm{rein}}$ and qunrein refer to bearing pressure of the footing placed on geocell reinforced soil and unreinforced soil, respectively, considering identical footings at a specified settlement ratio, $\mathrm{s}_{\mathrm{i}} / \mathrm{B}(\%)$

\subsection{General Load-Settlement Behavior}

Figure 6 shows the bearing stress versus settlement curves for footings placed on unreinforced soil with different widths in two different relative densities. As seen, the trend of diagrams is almost similar for the same relative density.

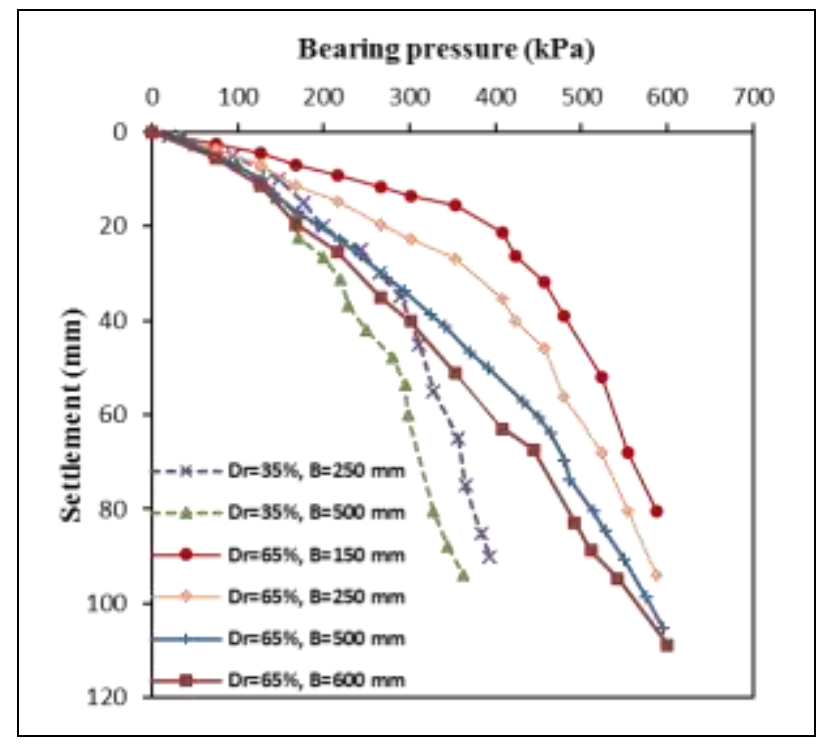

Figure 6. Bearing pressure versus settlement curve for the test series 1 and 2

In both relative densities of $35 \%$ and $65 \%$, the settlement of footing increases with increasing the footing width. As seen in Figure 6, the load-settlement behavior of footings with different widths seems identical in small settlements. While, as the settlement increases, a greater divergence is observed in load-settlement behavior of footings with different widths. This divergence occurs in the soil with less relative density $\left(D_{r}=35 \%\right)$ during small settlements. This is because the looser sand approaches to failure state at smaller settlements compared with denser soils. Differences in the behavior of footings with the same dimensions placed on soils with two different relative densities is observed when $\mathrm{s} / \mathrm{B}>5 \%$. Thus, the soil density has a negligible effect on the behavior footing in small settlements.

To check the validity of the test results of this study and trend of pressure versus settlement curves for different size of footings supported on unreinforced sand, the authors considered it useful to compare results of this study with other studies. Briaud and Gibbens [4] performed several in-situ square footings (i.e., 1, 2, 2.5 and $3 \mathrm{~m}$ ) load tests on sandy soils and results are shown in Figure 7. As seen in Figures 6 and 7, the trend of diagrams is almost similar and in the same applied pressure, the settlement becomes larger by increasing the width of the footing. Adams and Collin [2] reported somewhat similar findings for load-settlement behavior of square footings on unreinforced and geocellreinforced sand. 


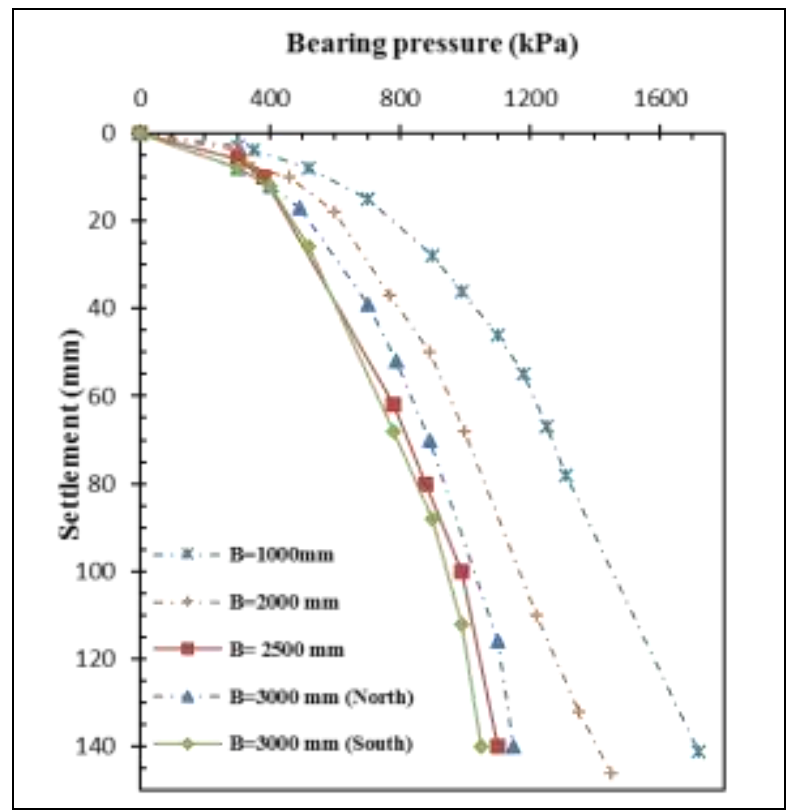

Figure 7. Bearing pressure versus settlement curve for footings on silty sand (data from [4])

Figure 8 shows the changes in bearing pressure versus settlement for footings with different widths placed on the reinforced soil with two different relative densities. Evidently, the changing trend of load-settlement curve is the same for all dimensions of footing in the reinforced soil with different relative densities. In reinforced soils, like unreinforced soils, the footing settlement increases as footing width rises in the same bearing pressure. In reinforced conditions, as shown in Figure 8, no clear failure is visible in footings with different dimensions even at large settlements. Dash et al. and Hegde and Sitharam reported similar results for geocell reinforced soils in small-scale tests $[6,16,17]$.

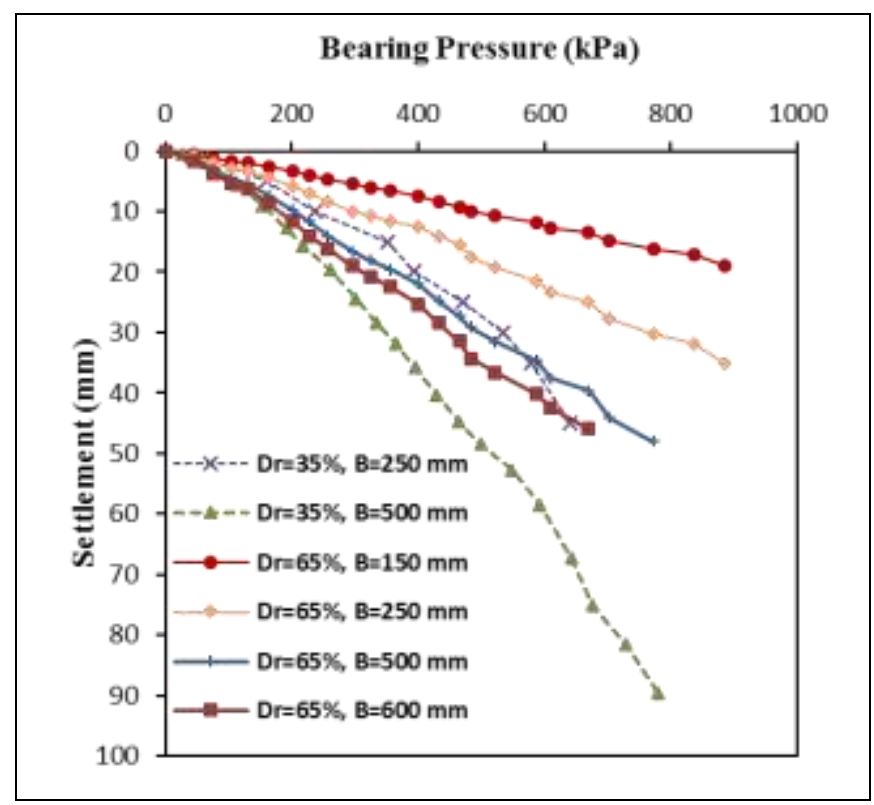

Figure 8. Changes in bearing pressure versus settlement for the test series 3 and 4

As shown in Figure 8, like unreinforced states, the load-settlement behavior of footings with different widths is similar in reinforced conditions and the divergence in load-settlement behavior of footings with different widths appears by increasing the settlement. The divergence occurs in the soil with less relative density $\left(\mathrm{D}_{\mathrm{r}}=35 \%\right)$ in smaller settlements. Figure 9 shows the bearing pressure versus settlement ratio for different $\mathrm{u} / \mathrm{B}$ (test series 5). These tests include reinforcement depth ratios $(\mathrm{u} / \mathrm{B})$ of $0.1,0.3,0.54$ and 0.9 . Obviously, as the reinforcement depth increases, larger settlements occur for the same bearing pressure. In other words, the efficiency and effectiveness of reinforcement decline by increasing the $\mathrm{u} / \mathrm{B}$. It may be because of the fact that as the $\mathrm{u} / \mathrm{B}$ increases, the footing applied pressure is distributed within the unreinforced soil mass above geocell mattress and the behavior of footing approaches the unreinforced conditions. 


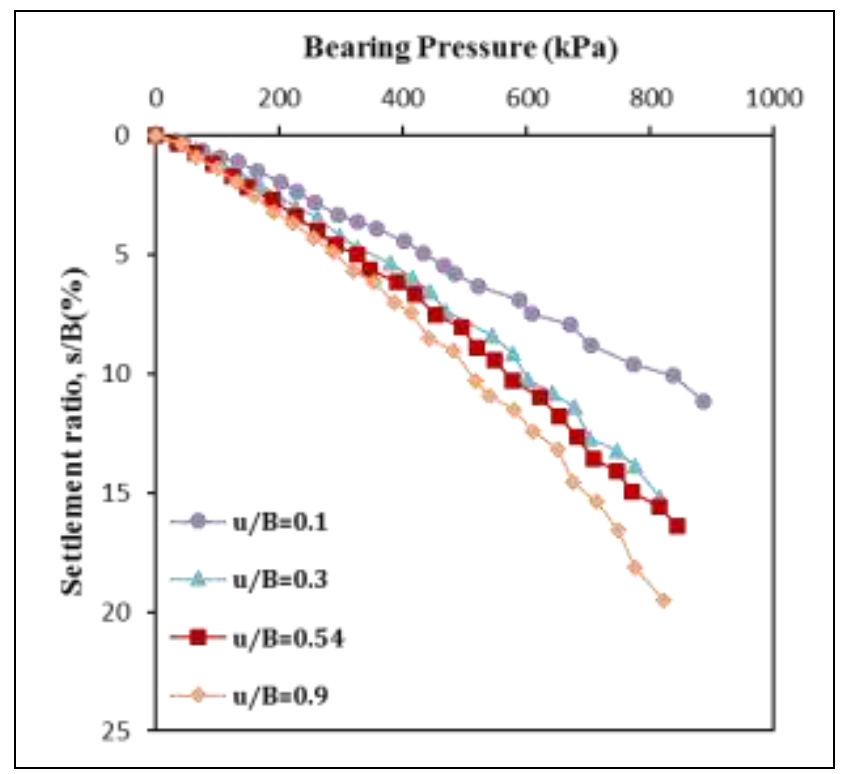

Figure 9. Bearing pressure versus $\mathrm{S} / \mathrm{B}$ curve for the test series 5

\subsection{Effect of Footing Width on Scale Effect}

Test series 1 and 3 were conducted to investigate the effect of footing dimensions on scale effect. Table 4 represents the bearing pressure (q) at $\mathrm{s} / \mathrm{B}=10 \%$ for footings with different dimensions in reinforced and unreinforced conditions with two different relative densities. The values of $\mathrm{N}_{\gamma}$ and IF are also calculated in Table 4.

Table 4 shows that as the footing width increases, the $\mathrm{N}_{\gamma}$ decreases for different densities in unreinforced and reinforced soils. Therefore, like unreinforced granular soils, the tests results and load-settlement behavior depend on the scale effect in reinforced granular soils and the extrapolation of the results of small-scale tests to full-scale footings lead to a non-conservative estimation. The $\mathrm{N}_{\gamma}$ value is reduced to about $70 \%$ in unreinforced and reinforced soils with $\mathrm{D}_{\mathrm{r}}=$ $65 \%$ for changing footing width of 150 to $600 \mathrm{~mm}$. This indicates that the effect of footing width on scale effect have the same trend at this relative density for both unreinforced and reinforced conditions.

Table 4. $\mathbf{N}_{\gamma}$ and IF values for test series $1,2,3$ and 4

\begin{tabular}{ccccccc}
\hline Test number & Reinforcement & $\mathbf{B}(\mathbf{m m})$ & $\mathbf{D}_{\mathbf{r}}(\mathbf{\%})$ & $\mathbf{q u l t t}_{\mathbf{c}}(\mathbf{k P a})$ & $\mathbf{N}_{\gamma}$ & $\mathbf{I F}$ \\
\hline 1 & 250 & 35 & 243 & 75.1 & - \\
2 & & 500 & 35 & 265 & 40.9 & - \\
3 & \multirow{2}{*}{ Unreinforced } & 150 & 65 & 337 & 163.1 & - \\
4 & 250 & 65 & 331.2 & 96.2 & - \\
5 & 500 & 65 & 362.7 & 52.6 & - \\
6 & 600 & 65 & 396 & 47.9 & - \\
\hline \hline 7 & 250 & 35 & 470 & 145.4 & 1.93 \\
8 & 500 & 35 & 515 & 79.6 & 1.94 \\
9 & & 65 & 708 & 343 & 2.1 \\
10 & Reinforced & 250 & 65 & 670 & 194.7 & 2.02 \\
11 & & 500 & 65 & 825 & 119.9 & 2.27 \\
12 & 600 & 65 & 837 & 101.3 & 2.11 \\
\hline
\end{tabular}

Figure 10 shows the changes of $\mathrm{N}_{\gamma}$ versus the footing width for both reinforced and unreinforced soils at $\mathrm{D}_{\mathrm{r}}=65 \%$ for this study and test results performed on unreinforced sand at $\mathrm{D}_{\mathrm{r}}=45 \%$ by Cerato and Lutengger [5]. The curves follow the same trend for both reinforced and unreinforced conditions at different settlement studies. As shown in Figure 10, as the footing dimensions increases, changes in $\mathrm{N}_{\gamma}$ decline. In this research, for footings with dimensions larger than $500 \mathrm{~mm}$, scale effect is significantly reduced. Cerato and Lutengger and Al.Khuzaie reported similar results for unreinforced sand [5, 2]. 


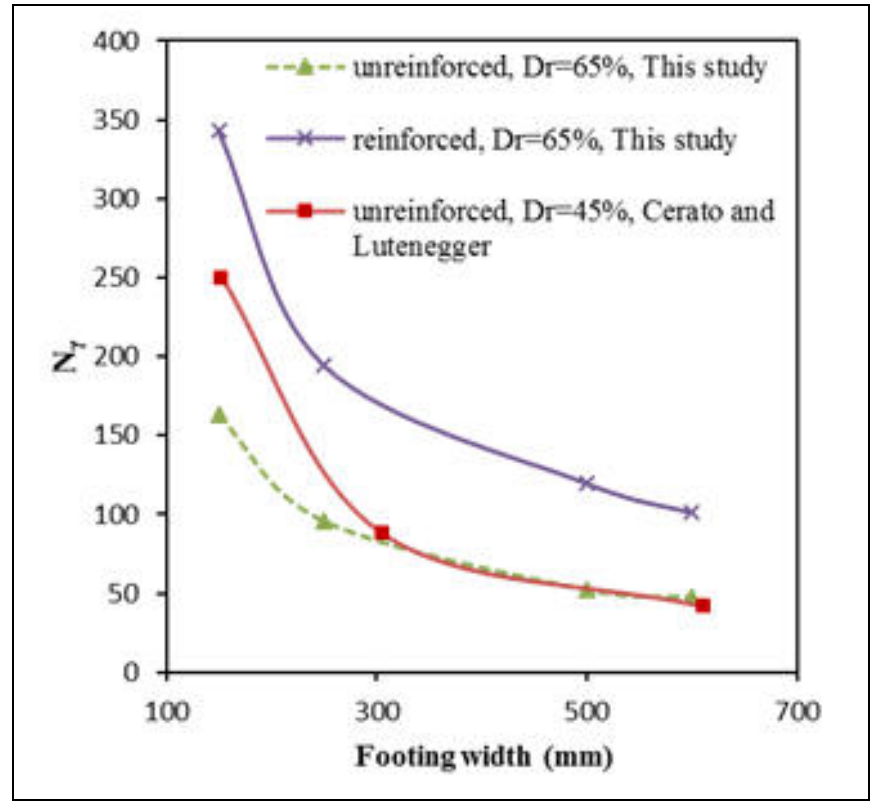

Figure 10. Changes of $\mathbf{N}_{\gamma}$ versus footing width for reinforced and unreinforced soil

\subsection{Effect of Relative Density on Scale Effect}

Figure 11 illustrates the changes in $\mathrm{N}_{\gamma}$ versus the footing width for both reinforced and unreinforced states with $\mathrm{s} / \mathrm{B}=10 \%$ at two relative densities of $\mathrm{D}_{\mathrm{r}}=35 \%$ and $65 \%$. It is clear that $\mathrm{N}_{\gamma}$ increases in both reinforced and unreinforced conditions for the same footing width by increasing the relative density. For example, the $\mathrm{N}_{\gamma}$ value for the $500 \mathrm{~mm}$ footing width in reinforced conditions increases by $51 \%$ when the relative density increases from $35 \%$ to $65 \%$. This increase is $31 \%$ for unreinforced soil. Therefore, the effect of density on scale effect is more significant in reinforced sand than unreinforced sand. As shown in Figure 11, the value of $\mathrm{N}_{\gamma}$ for a footing $250 \mathrm{~mm}$ wide at a relative density of $35 \%$ is equivalent to that of a footing measuring approximately $380 \mathrm{~mm}$ wide at a relative density of $65 \%$ in reinforced state. In unreinforced sand, the value of $\mathrm{N}_{\gamma}$ for $250 \mathrm{~mm}$ footing width at $\mathrm{D}_{\mathrm{r}}=35 \%$ is equal to that of a footing width of about $350 \mathrm{~mm}$ at $\mathrm{D}_{\mathrm{r}}=65 \%$. Therefore, it can be concluded that the behavior in small-scale tests does not directly indicate the behavior of full-scale footings. This is because of the fact that the mean stress under the footing varies for different dimensions, causing different initial conditions versus the critical state line even in similar densities. For example, if two footings with different widths (different mean stresses) are placed on a sand bed with the same density, the behavior of larger footing with a higher mean stress is closer to the critical state line, resembling when it is placed on the loose soil. Therefore, larger footing creates larger settlements for a given pressure compared to the smaller footing. In order to correlate a model-scale test to full-scale test, one would have to perform a model-scale test on a looser state of sand than what was required for a full- scale test. Cerato and Lutengger reported similar results for unreinforced soil [5].

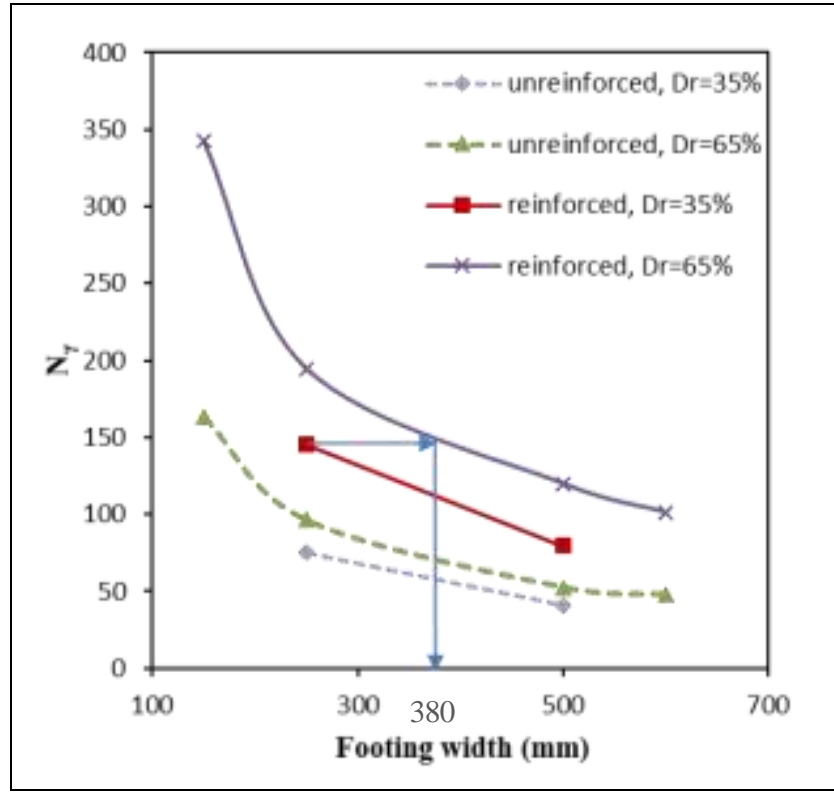

Figure 11. Changes in $\mathbf{N}_{\gamma}$ versus footing width for unreinforced and reinforced sand with two densities 


\subsection{Effect of Reinforcement Depth on Scale Effect}

In reinforced soils, a parameter that influences the scale effect and behavior of footing is the reinforcement depth (u). This section aims to examine the possibility of generalizing the results of small-scale tests to full-scale footings, considering a constant value of $\mathrm{u} / \mathrm{B}$. Test series 5 were conducted to assess the effect of reinforcement depth on bearing pressure and scale effect. The condition of $\mathrm{u} / \mathrm{B}=0$ is not considered in test series to prevent the early buckling of geocell walls due to direct contact with the bottom of footing. Dash et al. reported the reduction of bearing pressure and reinforcement efficiency at $\mathrm{u} / \mathrm{B}=0[6]$.

Figure 12 shows the changes in IF versus $\mathrm{u} / \mathrm{B}$ for footings with various $\mathrm{B}$ at $\mathrm{s} / \mathrm{B}=10 \%$ for reinforced sand. The value of IF decreases and approaches unity as the reinforcement depth increases. It can be argued that as the reinforcement depth increases, the footing applied pressures are distributed within the unreinforced soil above the reinforcement and the behavior of footing approaches that of a footing placed on reinforced soil. Dash et al. and Sitharam and Sireesh reported similar results for geocell reinforcement in small-scale experiments [16, 26]. As shown in Figure 12, for $\mathrm{u} / \mathrm{B}>$ 0.3 , the effect of reinforcement decreases and IF decreases with increasing $\mathrm{u} / \mathrm{B}$. According to Figure 12 , smaller footings exhibit greater improvement than the larger ones at the same reinforcement depths. For example, for a footing with $\mathrm{B}=150 \mathrm{~mm}$ and for $\mathrm{u} / \mathrm{B}=0.3$, the $\mathrm{IF}$ value becomes 2.1 , whereas $\mathrm{IF}=1.64$ is for a footing with $\mathrm{B}=500 \mathrm{~mm}$ at the same $\mathrm{u} / \mathrm{B}=0.3$. Therefore, the scale effect is not eliminated even in case of appropriate ratio of reinforcement depth $(\mathrm{u} / \mathrm{B})$ and the results of small-scale tests cannot be directly used for larger footings because small-scale tests overestimate the values of IF. In other words, using the results of small-scale tests for larger footings is not conservative and this should be considered in the design and construction of footings.

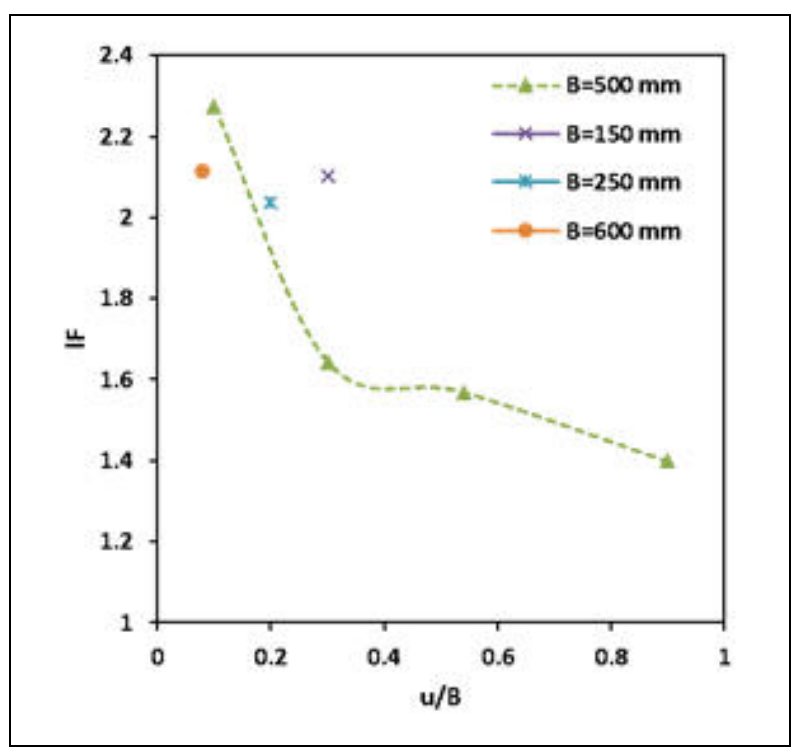

Figure 12. Variation of IF versus $u / B$ for various $B$ at $s / B=10 \%$

\section{Limitations and Applicability}

In this research, due to difficulties associated with sample preparation, time-consumption in conducting tests, providing homogenous soil bed, large dimension of the test tank and costs involved, the obtained results are based on considered geocell type, pocket size of geocell, height of geocell, sand type, soil grain size distribution, footing shape, plate stiffness, tensile strength of geocell wall sheets, footing applied pressure, test preparation method, etc. Therefore, further studies are recommended to consider the effect of other variable values on results and application in full scale should only be made after considering the above limitations.

The presented results are helpful to understand the basic mechanism and behavior of footings on geocell-reinforced sand. Considering the changes in the footing widths in this research, the results of this study can be used to estimate the modulus of subgrade reaction of geocell-reinforced sand. The results could be helpful in designing large scale model tests and their simulating through numerical models. Using the results of this research and dimensional analysis, the behavior of small scale models can be extrapolated to full scale footings on geocell reinforced sand.

\section{Conclusion}

A series of large-scale loading tests were carried out on rigid square plates of different widths placed on unreinforced and geocell-reinforced soils with different densities. The main results are:

- For small footing settlements, the load-settlement behavior of footings with different widths is similar to each other and as the settlement increases, the divergence is considerably observed in the load-settlement behavior of 
footings of different widths. As the footing width increases, the footing settlement increases at the same pressure in both unreinforced and reinforced soil.

- Similar to unreinforced granular soil, the load-settlement behavior of footing depends on scale effect in the geocellreinforced granular soil and the generalization of the results of small-scale tests to full-scale footings leads to nonconservative estimations. As the footing width increases from $150 \mathrm{~mm}$ to $600 \mathrm{~mm}$ at $\mathrm{D}_{\mathrm{r}}=65 \%$, the value of $\mathrm{N}_{\gamma}$ decreases by $70 \%$ for both unreinforced and reinforced sand. This indicates a similar effect of footing width on scale effect in both unreinforced and reinforced sand.

- With increasing the footing width, the value of $\mathrm{N}_{\gamma}$ decreases. In addition, the rate of reduction decreases. For footing with dimension larger than $500 \mathrm{~mm}$, scale effect is significantly reduced. The behavior observed in smallscale tests cannot be directly used to estimate the behavior of full-scale footings. Small-scale tests usually provide non-conservative results for larger footings. To overcome this problem, small-scale tests can be carried out on sand with a lower density than the sand used for large-scale tests.

- For a given $\mathrm{u} / \mathrm{B}$, smaller footings exhibit greater improvement (IF) than larger footings. Therefore, the scale effect is not eliminated at the same $\mathrm{u} / \mathrm{B}$ and using the results of small-scale tests for larger footings is not conservative.

\section{References}

[1] Adams, Michael T., and James G. Collin. "Large Model Spread Footing Load Tests on Geosynthetic Reinforced Soil Foundations." Journal of Geotechnical and Geoenvironmental Engineering 123, no. 1 (January 1997): 66-72. doi:10.1061/(asce)10900241(1997)123:1(66).

[2] Al Khuzaie, H.M. "Verification of Scale Effect of Shallow Foundation in Determination of Bearing Capacity of Sandy Soil." AlRafadain Engineering Journal 19, no. 2 (2011).

[3] ASTM D1196M, (2012). "Test Method for Nonrepetitive Static Plate Load Tests of Soils and Flexible Pavement Components, for Use in Evaluation and Design of Airport and Highway Pavements" (n.d.). doi:10.1520/d1196-93r04.

[4] Briaud, Jean-Louis, and Robert Gibbens. "Behavior of Five Large Spread Footings in Sand." Journal of Geotechnical and Geoenvironmental Engineering 125, no. 9 (September 1999): 787-796. doi:10.1061/(asce)1090-0241(1999)125:9(787).

[5] Cerato, Amy B., and Alan J. Lutenegger. "Scale Effects of Shallow Foundation Bearing Capacity on Granular Material." Journal of Geotechnical and Geoenvironmental Engineering 133, no. 10 (October 2007): 1192-1202. doi:10.1061/(asce) 10900241(2007)133:10(1192).

[6] Dash, S. "Bearing Capacity of Strip Footings Supported on Geocell-Reinforced Sand." Geotextiles and Geomembranes 19, no. 4 (May 2001): 235-256. doi:10.1016/s0266-1144(01)00006-1.

[7] Dash, Sujit Kumar, K Rajagopal, and N.R Krishnaswamy. "Strip Footing on Geocell Reinforced Sand Beds with Additional Planar Reinforcement.” Geotextiles and Geomembranes 19, no. 8 (December 2001): 529-538. doi:10.1016/s0266-1144(01)00022-x.

[8] Dash, S. "Model Studies on Circular Footing Supported on Geocell Reinforced Sand Underlain by Soft Clay." Geotextiles and Geomembranes 21, no. 4 (August 2003): 197-219. doi:10.1016/s0266-1144(03)00017-7.

[9] Dash, S. K., K. Rajagopal, and N. R. Krishnaswamy. "Performance of Different Geosynthetic Reinforcement Materials in Sand Foundations." Geosynthetics International 11, no. 1 (January 2004): 35-42. doi:10.1680/gein.11.1.35.36317.

[10] Dash, Sujit Kumar. "Effect of Geocell Type on Load-Carrying Mechanisms of Geocell-Reinforced Sand Foundations." International Journal of Geomechanics 12, no. 5 (October 2012): 537-548. doi:10.1061/(asce)gm.1943-5622.0000162.

[11] De Beer, E. E. "The Scale Effect in the Transposition of the Results of Deep-Sounding Tests on the Ultimate Bearing Capacity of Piles and Caisson Foundations.” Géotechnique 13, no. 1 (March 1963): 39-75. doi:10.1680/geot.1963.13.1.39.

[12] DeMerchant, M.R, A.J Valsangkar, and A.B Schriver. "Plate Load Tests on Geogrid-Reinforced Expanded Shale Lightweight Aggregate.” Geotextiles and Geomembranes 20, no. 3 (June 2002): 173-190. doi:10.1016/s0266-1144(02)00006-7.

[13] Fakher, Ali, and Colin J. F. P. Jones. "Discussion: Bearing Capacity of Rectangular Footings on Geogrid-Reinforced Sand." Journal of Geotechnical Engineering 122, no. 4 (April 1996): 326-327. doi:10.1061/(asce)0733-9410(1996)122:4(326).

[14] Ghazavi, Mahmoud, and Arash Alimardani Lavasan. "Interference Effect of Shallow Foundations Constructed on Sand Reinforced with Geosynthetics." Geotextiles and Geomembranes 26, no. 5 (October 2008): 404-415. doi:10.1016/j.geotexmem.2008.02.003.

[15] Golder, H.Q, Fellenius, W, Kogler, F, Meischeider, H, Krey, H, and Prandtl, M. "The Ultimate Bearing Pressure of Rectangular Footings.” Journal of the Institution of Civil Engineers 17, no. 2 (December 1941): 161-174. doi:10.1680/ijoti.1941.13728.

[16] Hegde, A., and T.G. Sitharam. "3-Dimensional Numerical Modelling of Geocell Reinforced Sand Beds." Geotextiles and Geomembranes 43, no. 2 (April 2015): 171-181. doi:10.1016/ j.geotexmem.2014.11.009.

[17] Hegde, A., and T.G. Sitharam. "Experimental and Numerical Studies on Protection of Buried Pipelines and Underground Utilities Using Geocells." Geotextiles and Geomembranes 43, no. 5 (October 2015): 372-381. doi:10.1016/j.geotexmem.2015.04.010.

[18] Hegde, A., and T.G. Sitharam. "Experiment and 3D-Numerical Studies on Soft Clay Bed Reinforced with Different Types of Cellular Confinement Systems.” Transportation Geotechnics 10 (March 2017): 73-84. doi: 10.1016/j.trgeo.2017.01.001. 
[19] Hettler, A., and Gudehus, G. "Influence of the Foundation Width on the Bearing Capacity Fact or." Soils and Foundations 28, no. 4 (1988): 81-92. doi:10.3208/sandf1972.28.4_81.

[20] Kusakabe, O. "Foundations.” Geotechnical Centrifuge Technology (n.d.): 118-167. doi:10.4324/ 9780203210536_chapter_6.

[21] Lavasan, Arash Alimardani, and Mahmoud Ghazavi. "Behavior of Closely Spaced Square and Circular Footings on Reinforced Sand.” Soils and Foundations 52, no. 1 (February 2012): 160-167. doi:10.1016/j.sandf.2012.01.006.

[22] Lavasan, Arash Alimardani, Mahmoud Ghazavi, and Tom Schanz. "Analysis of Interfering Circular Footings on Reinforced Soil by Physical and Numerical Approaches Considering Strain-Dependent Stiffness.” International Journal of Geomechanics 17, no. 11 (November 2017): 04017096. doi:10.1061/(asce)gm.1943-5622.0000992.

[23] Oliaei, Mohammad, and Saeed Kouzegaran. "Efficiency of Cellular Geosynthetics for Foundation Reinforcement." Geotextiles and Geomembranes 45, no. 2 (April 2017): 11-22. doi:10.1016/ j.geotexmem.2016.11.001.

[24] Shadmand, A., M. Ghazavi, and N. Ganjian. "Load-Settlement Characteristics of Large-Scale Square Footing on Sand Reinforced with Opening Geocell Reinforcement." Geotextiles and Geomembranes 46, no. 3 (June 2018): 319-326. doi:10.1016/j.geotexmem.2018.01.001.

[25] Shiraishi, S. "Variation in Bearing Capacity Factors of Dense Sand Assessed by Model Loading Tests." Soils and Foundations 30, no. 1 (1990): 17-26. doi:10.3208/sandf1972.30.17.

[26] Sitharam, T.G., and S Sireesh. "Behavior of Embedded Footings Supported on Geogrid Cell Reinforced Foundation Beds." Geotechnical Testing Journal 28, no. 5 (2005): 12751. doi:10.1520/gtj12751.

[27] Terzaghi, Karl. “Theoretical Soil Mechanics” (January 1, 1943). doi:10.1002/9780470172766.

[28] Ueno, Katsutoshi, Kinya Miura, and Yoshito Maeda. "Prediction of Ultimate Bearing Capacity of Surface Footings with Regard to Size Effects." Soils and Foundations 38, no. 3 (1998): 165-178. doi:10.3208/sandf.38.3_165. 